\title{
Female Psyche and Search for Self-hood in Shashi Deshpande's The Dark Holds No Terrors
}

\section{OPEN ACCESS}

Manuscript ID:

ENG-2021-09033899

Volume: 9

Issue: 3

Month: June

Year: 2021

P-ISSN: 2320-2645

E-ISSN: 2582-3531

Received: 14.04.2021

Accepted: 20.04.2021

Published: 01.06.2021

Citation:

Joseph, Padma, and

Krishnaraj. "Female Psyche and Search for Self-Hood in Shashi Deshpande's The Dark Holds No Terrors." Shanlax International Journal of English, vol. 9, no. 3, 2021, pp. 61-63.

DOI:

https://doi.org/10.34293/

english.v9i3.3899

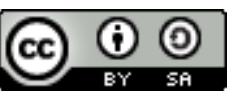

This work is licensed under a Creative Commons Attribution-ShareAlike 4.0 International License

\author{
Padma Joseph \\ Research Scholar in English \\ Kandaswami Kandar's College, Velur, Namakkal, Tamil Nadu, India
}

\section{Krishnaraj}

Associate Professor \& Head, Department of English

Kandaswami Kandar's College, Velur, Namakkal, Tamil Nadu, India

\begin{abstract}
The place of women in society has differed from culture to culture and from age to age, yet one fact common to almost all societies is that woman has never been considered the equal of men. Her status largely depends on the simple biological fact that she is the bearer of children. In this way her sphere is usually restricted to her familial role. Immemorial woman has been the victim of male domination and oppression and treated like a beast of burden of burden and an object for pleasure. Man has always looked down upon her as the weaker sex, as his property, servile to him. Different religions of the world have given sanction to the female's subjection to the male members of society, thus perpetuating the women; wives, submit yourselves to your husband's to the lord woman as regarded subordinate to man because it is believed that she was made out of man. This present paper attempts to analysis researcher's chosen novel The Dark Holds No Terrors by Shashi Deshpande. Her novels appeared as a voice against the tormented women aimed to create a mass awareness against the suppression and the repression of the corrupted patriarchal society. She focus in her fiction is essentially on women's role in society.
\end{abstract}

Keywords: Biological, Male domination, Oppression, Weaker sex, Patriarchal

\section{Society}

The dawn of the twentieth century was characterized by significant political, social and Economic changes. It was also a period of deep intellectual reappraisal, and a period of psychological discoveries. These factors had a deep impact on Indian English fiction. Indian English fiction which had been in the queer state of porousness saw a flourish and steady growth during the fifties and later. It was mainly realistic in pattern. The writers identified the problems amidst growing individualistic pattern of behaviour. They mostly deal with the problems of behavior, human relationship and emphasized the element of reality and individuality.

In Indian-English fiction too, though the new woman finds recognition of her existence and support for her cause from some quarters, she makes her appearance in flesh and blood in the novels of a women writer. The problems of women have been raised in works of many Indians writing in English. Bhabani Bhattacharya, Kamala Das, Nayantara Shagal, Anita Desai, Shashi Deshpande, Namita Gokhale, Shoba De and Arundhati Roy - are few of the prominent names in this field. Kamala Das may, perhaps said to be the first voice of the women by a woman. A variety of shades of a women's mind and plight is reflected through the Indian writing in English. 
Fiction by women writers constituted a major segment of the contemporary Indian writing in English. The women novelist focused their attention on women's issues. They presented a large part of the feminine experience which was out of reach of the male psyche. An authentic and sensitive portrayal of the conflicts and traumas in all their nuances, ambiguities and contradictions would be achieved only by women writers. These women writers attempted to write constructively and to present role models of the oppressed women. There were also primarily concerned with the recognition of women as a being. Their women are presented as individuals craving for identity. These writers also focused their attention on modern women as an individual in the family and society.

Shashi Deshpande was born in Dharwad in the year 1938. She received her University education, a graduate degree, in Bombay and Bangalore. Deshpande has degrees in Economics and law also. When Shashi Deshpande was living in Mumbai, She did a course on journalism at the Bharathiya Vidya Bhavan and worked for the magazine "On looker". She has published her first collection of short stories in 1978, and first novel, The Dark Holds No Terrors in 1980. Deshpande won the Sahitya Academy Award for the novel That long silence in 1988 and the Padma shri Award in 2009. Her other novels are If I Die Today 1982. Come Up And Be Dead 1983 Roots And Shadows 1983. The Binding Vine 1992, The Intrusion and Other Stories 1993, A Matter of Time and The Narayanpur Incident 1982. Shashi Deshpande has also written four children's books, a number of short stories. Her best-known short story is The Legacy and it has been prescribed by Columbia University in its literature syllabus.

Shashi Deshpande tries to address particularly the problem of the middle-class working women. Her career women try to redefine human relationship in view of the newly acquired professional status. The social and cultural change in the post-independence India has made the women conscious of the need to define themselves, their surroundings. Shashi Deshpande's concern is to explore the root cause of the fragmentation and dichotomy of her character and to find out what happens in the psyche of these heroines in the process of individuation.
Deshphande, an outstanding novelist of Indian English literature highlights the problems encountered by the Indian women caught between the native Indian and invading western cultures. There are two types of experiences from leaving one's own home and from an invading culture the physical and psychic disturbances of wandering between two worlds - physical here and mentally there make for creativity new vistas and avenues.

Deshpande carefully avoids the western feminist's concept of emancipation and presents the Indian version of the modern woman who searches for the whole of her 'identity' and not fragmentations of herself. Deshpande cautiously puts aside the western notion of her life partner, for an existence without any relation to male and society, a life an isolation is no existence.

Saru, the protagonist of Shashi Deshpande's The Dark Holds No Terrors searches for herself and ultimately grows into an individual rather than an object pinned down by the Indian society to gender roles. Saru chooses the western education and becomes a doctor by profession but fails as a wife, for her male counterpart is a typical Indian who considers himself the lord and master. First her mother, a symbol of Indian orthodoxy, hates Saru for being a girl, now the dominating Indian husband takes himself for a demy god and treats her as an unpaid servant.

Saru's kid brother Dhruva is her primary target in her contestation with male power. Being a son, he had the advantage of receiving more attention, care to the fore front when she pushes him from her father's lap when he was hardly a year old. He had been completely loyal to her in all respects, always running after his beloved Sarita. But she spared no occasion to assert her authority over him on every opportunity. It seems, at first, that against the patriarchal power of domination, her relationship with Dhruva forms the battle ground on which she is fighting for a space of her own.

The complex relationship between a successful doctor, and her professionally frustrated and irritated husband just because the wife has a better job, there is a very obvious tension between them that subsequently leads them to separate from each other. Another common factor to observe in the novel's 
that the woman presented is not complete in herself. Unless there is someone to shelter her, whether it be her father, brother or husband. Saru's profession as a doctor gives her power and identity gives her comfort and identity. This capacity to create and give happiness gives one an identity. This is the identity that Saru searched for which gave her the recognition.

Thus the novel ends with the certainty that how Saru will no longer be a victim of guilt for someone else's failure. A confident Saru realizes that the essence of any marriage is understanding and mutual respect and not subjugation of one by the other. The novel end with an optimistic note with the hope of some positive action in take her back and start their life a fresh; actually this going to her husband is not to endure the humiliation but to cure her husband from the depression and bring happiness in her family life.

In the novel The Dark Hold No Terrors all the characteristics are inextricably blended, in Saru who represents a reaction of society. Saru is brought up in a traditional atmosphere but the education that she received makes her a changed person with a rebellious attitude towards tradition. Manohar's male ego tries to dominate Sarita which ultimately results in disintegration, that Sarita is an individual not a dependent but a capable of withstanding trials in life along. Her identity is no longer been in terms of the identity of her male counterpart.

The discriminating socio-cultural values, attitudes and practices which cripple the personality of the female child are high-lighted in the novel. A girl child is unwanted at birth and neglected during childhood and adolescence. Saru suffers from gender discrimination right from her birth. She is unwelcome in the family because her parent's preference is for a male child as their first-born.

Thus, the themes that have found expression in this novelare inner conflict and search for identity.

Parent-child relationship, and concept of marriage and sex. Above all the themes of silence rooted in the complex relationship between man and woman hold a great fascination for Shashi Deshpande. She deals with the inner working of the female psyche.

\section{References}

Amala, S., and G. Somasundaram. "The Role of Fate and Chance in Shashi Deshpande's The Dark Holds No Terrors." Literary Endeavour, vol. 7, no. 2, 2016, pp. 58-60.

Ambika, S. "Woman: Her-Self and the Other, Conflict and Resolution in The Dark Holds No Terrors." Studies in Women Writers in English. Edited by Mohit K. Ray, and Rama Kundu, Atlantic Publishers, 2004.

Gunaseelan, Poonkulaly. "Splitting/Violating the "New Indian Woman" in Shashi Deshpande's The Dark Holds No Terrors (1980)." Zeitschrift für Anglistik und Amerikanistik, vol. 66, no. 1, 2018.

Nayar, Pramod K. Postcolonial Literature: An Introduction. Pearson Education, 2008.

Prajapati, Rajesh S. "The Plight of Women in Indian Society Depicted in "The Dark Holds No Terrors" by Shashi Deshpande." International Journal of Research and Analytical Reviews, vol. 2, no. 4, 2015, pp. 59-63.

Ramya, C. "Saru in Shashi Deshpande's The Dark Holds No Terrors." Language in India, vol. 20, 2020, pp. 72-81.

Sugasini, N. "Quest for Identity in Shashi Deshpande's The Dark Holds No Terrors." Journal of English Language Teaching and Literary Studies, vol. 5, no. 1, 2016.

Uma, R. "Compendium of the Crisis of the Educated Earning Women in Shashi Deshpande's The Dark Holds No Terror." Shanlax International Journal of English, vol. 6, no. 2, 2018, pp. 202-208.

\section{Author Details}

Padma Joseph, Research Scholar in English, Kandaswami Kandar's College, Velur, Namakkal, Tamil Nadu, India

Dr. Krishnaraj, Associate Professor \& Head, Department of English, Kandaswami Kandar's College, Velur, Namakkal, Tamil Nadu, India 